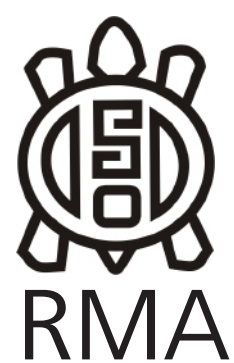

Dossier

\title{
Estudio preliminar de los hallazgos de Canis familiaris en la Pirámide con Rampa $N^{\circ}$, Santuario de Pachacamac, Perú
}

\author{
Denise Pozzi-Escot*, Isabel Cornejo Rivera*, \\ Enrique Angulo Costaneira* y Katiusha Bernuy Quiroga*
}

*Museo de Sitio de Pachacamac (MSPACH); Ministerio de Cultura; Perú. E-mail: dpozzi@mcultura.gob.pe; icornejo@mcultura.gob.pe; huamachito@yahoo.com; kbernuy@mcultura.gob.pe

\begin{abstract}
Resumen
El Santuario arqueológico de Pachacamac tuvo una ocupación de alrededor de mil años, desde los primeros siglos de la era cristiana hasta la llegada de los conquistadores españoles al sitio. Durante el Horizonte Tardío (14701533 d.C.), bajo el dominio Inca fue el más importante conjunto ceremonial de la costa central peruana, al cual acudían peregrinos de diversos y lejanos lugares. Recientemente, en el acceso a la Pirámide con Rampa $N^{\circ} 7$ (PCR 07), conectado a la principal vía de ingreso al santuario conocida como Calle Norte-Sur, se realizó el hallazgo de seis cánidos en muy buen estado de conservación que fueron identificados como Canis familiaris. El estudio de este contexto nos permite proponer una reconstrucción fenotípica de un perro prehispánico tardío; asimismo, nos permite evaluar el papel que jugaron estos animales en la época Inca, y relacionarlo al carácter sagrado del santuario.
\end{abstract}

Palabras clave: Pachacamac; Pirámide con Rampa № 7; Canis familiaris; Horizonte Tardío; Inca.

Preliminary study of Canis familiaris remains in the Pyramid with Ramp Nㅜ7, Pachacamac Temple, Perú

\begin{abstract}
The Pachacamac Archeological Temple (Santuario de Pachacamac) was occupied for over a thousand years from the first centuries of the Christian era to the arrival of Spanish conquerors to the site. It was, during the Late Horizon (1470-1533 AD) and under the Inca rule, the most important ceremonial and pilgrimage center of the central coast of Peru. Recently, in the access to the Pyramid with Ramp $N^{\circ} 7$, connected to the main entrance road to the shrine known as North-South Street, six canines were found in very good condition, identified as Canis familiaris. The study of this context allows proposing a phenotypic reconstruction of a late pre-Hispanic dog, and evaluating the role played by these animals in the Inca period, and their interrelation with the temple's sacred nature.
\end{abstract}

Keywords: Pachacamac; Pyramid with Ramp N7; Canis familiaris; Late Horizon; Inca.

\section{Ubicación geográfica y cronológica del sitio}

El Santuario de Pachacamac se ubica en la Costa Central del Perú, en el departamento de Lima, a $31 \mathrm{Km}$ al sur de la ciudad de Lima en la margen derecha del río Lurín, sobre un afloramiento rocoso recubierto por arena de origen eólico que forma parte del tablazo ${ }^{1}$ de Lurín. El clima de la zona es característico de la costa central: árido, semicálido y húmedo. Una de las características geotectónicas es la actividad sísmica, cuyos movimientos alcanzan profundidades mayores a los $60 \mathrm{~km}$ (Pozzi-Escot y Chávez 2009).

El sitio limita por el Norte con el tablazo de Lurín y la Quebrada de Atocongo, por el Sur y Oeste con

\footnotetext{
${ }^{1}$ Término que se refiere a áreas elevadas sobre el nivel del mar, planas o llanas.
}

la desembocadura del río Lurín y con una zona de humedales, por el Este con el valle y las primeras estribaciones andinas (Figura 1).

Actualmente comprende un área de 465 hectáreas, donde se pueden identificar tres sectores delimitados por murallas. En el primero, el más elevado, se encuentran los principales Templos y edificaciones como el Templo Viejo, Templo de Pachacamac o Templo Pintado, el Templo del Sol y el cementerio Max Uhle. En el segundo, se encuentran 15 conjuntos de Pirámide con Rampa ${ }^{2}$ (PCR), la Plaza de los Peregrinos, la Sala Central, entre otras edificaciones. En el tercer sector se encuentran el Conjunto de Adobes Lima, también conocido como

\footnotetext{
2 Conocidas también por sus siglas como PCR, son conjuntos monumentales que se caracterizan por presentar dos plataformas unidas por una rampa central, una plaza frontal cercada, plazas laterales, depósitos y otros recintos.
} 


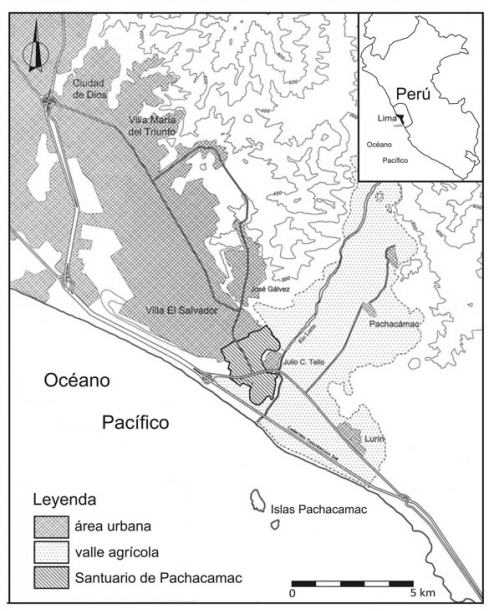

Figura 1. Mapa de ubicación del Santuario de Pachacamac, Perú.

Figure 1. Location map of Santuario de Pachacamac, Perú.

"Adobitos", el Acllawasi, además de las evidencias de dos lagunas, una zona de humedales, y un amplio sistema de canales (Pozzi-Escot y Bernuy 2010a). Este sector es atravesado por un eje de calles internas (Norte-Sur y Este-Oeste) que habrían mantenido conexión con el Gran Camino Inca o Qhapaq Ñan que articuló la región de los Andes Centrales durante el dominio incaico.

Construido básicamente en tierra y piedra, el santuario tuvo una ocupación de alrededor de mil años que se inicia desde los primeros siglos de la era cristiana (Tabla 1). Durante el Horizonte Tardío (1470-1533 d.C.), se construyeron una serie de edificaciones de clara filiación Inca como el Templo del Sol, la Plaza de los Peregrinos, el Acllawasi, el Edificio 47, entre otros y fueron reocupadas las edificaciones preexistentes como las PCR. El control Inca se manifestó por la presencia de infraestructura estatal en el sitio, el cual fue incorporado a su hegemonía dado el prestigio que tenía el oráculo de Pachacamac. En ese periodo, los Incas extendieron la fama del oráculo, por lo que acudían peregrinos desde diversos lugares para consultar al ídolo oracular que se encontraba en la zona nuclear de los templos (Eeckhout 2004a).

\section{Las investigaciones arqueológicas en la Calle Norte- Sur y PCR $\mathrm{N}^{\circ} 7$}

La Calle Norte-Sur debió ser la principal ruta de acceso y tránsito dentro del santuario hasta la llegada de los españoles en 1533. Por ello, como parte de sus componentes de Investigación y Conservación, el Museo de Sitio de Pachacamac desde el año 2009 inició un proyecto de investigación dirigido al:

"...estudio de la historia ocupacional del área ocupada por la Calle Norte-Sur y en la puesta en valor del tramo excavado, a fin de que los visitantes puedan observar la continuidad de la calle, comprender la relación de ésta con las PCR y conocer las características de su ocupación progresiva" (Pozzi-Escot y Bernuy 2010a:7).

Como resultado de las excavaciones realizadas en los años 2009 y 2010 se expuso un tramo de 160 metros de la calle y se definió que la misma fue construida en época Ychma (Intermedio Tardío, 1100-1470 d.C.), siendo usada y remodelada por los Incas, hasta que fue clausurada debido al colapso de parte de sus muros ocasionado por un movimiento sísmico de gran intensidad ocurrido durante la colonia (probablemente en 1687 o 1746). Además, se descubrieron los accesos a las $P C R$ 04 y PCR 07, lo cual puso en evidencia que la calle fue la principal vía de circulación interna hacia esas estructuras piramidales (Pozzi-Escot y Bernuy 2010b).

En el 2010 excavamos al pie del acceso que conectaba la calle Norte-Sur con una de las plazas laterales de la PCR 07. En uno de los últimos niveles de uso de esta plaza, que data del Horizonte Tardío (1470-1533 d.C.), hallamos los restos de seis canes en muy buen estado de conservación. Su estudio y la revisión de reportes de hallazgos similares en el santuario nos permiten caracterizarlos y evaluar el rol que habrían cumplido en la época del dominio Inca.

\section{Excavación: Estratigrafía y descripción de los hallazgos}

En el año 2010 excavamos el Pozo de Cateo 03, de $2 \mathrm{~m}$ x $2 \mathrm{~m}$., ubicado en una de las plazas laterales de la PCR 07 colindante a la calle Norte-Sur, al pie del acceso a la PCR, que probablemente fue clausurado a fines del Horizonte Tardío (1470-1533 d.C.). Esta intervención tuvo

\begin{tabular}{|c|c|c|c|}
\hline Cronología Relativa & $\begin{array}{c}\text { Cronología Absoluta (aproxi- } \\
\text { mada) }\end{array}$ & Cultura o Estilo & Edificaciones Principales \\
\hline Periodo Intermedio Temprano & $200-600$ D.C. & Lima & $\begin{array}{l}\text { Templo Viejo o Templo de Pachacamac, Templo } \\
\text { de Urpay Huachac y Complejo de Adobes Lima }\end{array}$ \\
\hline Periodo Horizonte Medio & $600-1100$ D.C. & $\begin{array}{l}\text { Estilos Epigonales e } \\
\text { influencia Wari }\end{array}$ & $\begin{array}{l}\text { Cementerio Uhle y Templo Pintado (Horizonte } \\
\text { Medio 3B) }\end{array}$ \\
\hline Periodo Intermedio Tardío & $1100-1470$ D.C. & Ychma & Pirámides con Rampa (PCR) y Calle Norte - Sur \\
\hline Periodo Horizonte Tardío & 1470 - 1533 D.C. & Inca & $\begin{array}{c}\text { Templo del Sol, Acllawasi y Plaza de los Pere- } \\
\text { grinos }\end{array}$ \\
\hline Periodo Colonial & 1533 D.C. - No determinado & Colonial & Reocupación del Acllawasi \\
\hline
\end{tabular}

Tabla 1. Cuadro Cronológico de ocupaciones del Santuario de Pachacamac

Table 1. Chronological chart of Santuario de Pachacamac's occupations. 


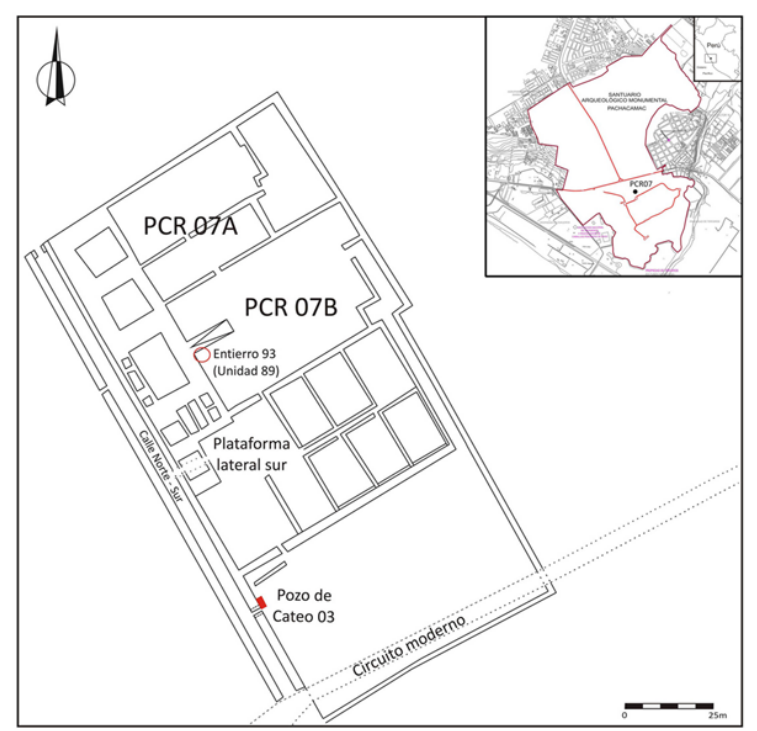

por objetivo comparar los resultados de este año con los obtenidos en el 2009, en cuanto a la relación cronológica y constructiva entre ambas edificaciones (Figura 2).

A partir de la secuencia estratigráfica del Pozo de Cateo 03 (Tabla 2) podemos observar que bajo el derrumbe
Figura 2: Plano del conjunto de la PCR 07 en el Santuario, con indicación de la ubicación del Pozo de Cateo 03.

Figure 2. PCR 07 sample in the temple, indicating Pozo de Cateo 03 location.

general del muro de la calle, que delimita ésta y la plaza lateral, producido por un intenso movimiento sísmico ocurrido durante la colonia (Pozzi-Escot y Bernuy 2009), se registró una acumulación de depósitos secundarios de basura que cubrían las capas 4 y 5 (Elemento 3$)^{3}$. De estas capas, asociadas a cerámica del estilo Inca, es de donde provienen los hallazgos de Canis familiaris registrados ${ }^{4}$ con los siguientes códigos: CNS426, CNS427, CNS428, CNS429, CNS430 y CNS431.

\section{Hallazgo CNS426}

Se trata de un pequeño fardo de unos $33 \mathrm{~cm}$ de largo por

\footnotetext{
${ }^{3}$ Se denominan Elementos a los contextos cerrados como: ofrendas, fogones, manchas de ceniza, concentraciones de basura, arquitectura.

${ }^{4}$ La codificación empleada corresponde a la utilizada en el registro de campo e inventario general de materiales del Proyecto de Investigación Arqueológica Calle Norte-Sur 2010, el cual está basado en algunas de las siglas del proyecto y el empleo de números arábigos correlativos y únicos. CNS corresponde a las siglas: Calle Norte-Sur.
}

\begin{tabular}{|c|c|c|}
\hline Capa & Nivel / Elemento & Descripción \\
\hline 1 & - & $\begin{array}{l}\text { Capa de arena de origen eólico. Contenía algunos fragmentos de cerámica del estilo Inca y restos del diario } \\
\text { "El Comercio" del año } 1931 .\end{array}$ \\
\hline 2 & 1 & $\begin{array}{l}\text { Corresponde al derrumbe general de los muros producido por un movimiento sísmico ocurrido en época } \\
\text { colonial (1687 o 1746). }\end{array}$ \\
\hline 2 & 2 & Capa de arena de origen eólico. Este nivel señala el abandono en el uso de este espacio. \\
\hline 3 & Elemento 1 & $\begin{array}{l}\text { Concentración de basura secundaria depositada exprofeso para "clausurar" el acceso y la ampliación de éste. } \\
\text { Por el material asociado, se sugiere que la "clausura" fue realizada en la época transicional o colonial. }\end{array}$ \\
\hline 3 & 1 & Nivel de basura sobre el que se depositó el Elemento 1. \\
\hline 3 & 2 & $\begin{array}{l}\text { Nivel de basura con abundante ceniza y restos materiales. Entre los restos óseos, se encontraron algunos } \\
\text { pertenecientes a la falange de un ave introducida (¿Gallus gallus?). }\end{array}$ \\
\hline 3 & 3 & $\begin{array}{l}\text { Nivel de basura secundaria. Entre el material óseo se encontraron restos correspondientes a la falange de un } \\
\text { mamífero introducido. }\end{array}$ \\
\hline 3 & 4 & $\begin{array}{l}\text { Este nivel, se relaciona directamente con la apertura o ampliación del acceso y el uso del mismo. El material } \\
\text { cerámico corresponde a fragmentos de vasijas del estilo Inca e Ychma. }\end{array}$ \\
\hline 3 & 4 - Elemento 2 & $\begin{array}{l}\text { Intrusión que corre al pie del muro. Removió parte del Elemento } 3 \text { y varias capas que probablemente se } \\
\text { asociaban al muro. }\end{array}$ \\
\hline 3 & 5 & $\begin{array}{l}\text { Restos de material orgánico (¿festines?) asociados a las actividades realizadas en la plaza. El material cerámi- } \\
\text { co corresponde a los estilos Inca e Ychma. }\end{array}$ \\
\hline 4 & - & Apisonado. Tenia una intrusión donde se encontraba el fardo pequeño de un perro (Hallazgo CNS426). \\
\hline 5 & Elemento 3 & $\begin{array}{l}\text { Concentración de basura secundaria donde se encontraron los restos de cinco perros momificados (Hallaz- } \\
\text { gos: CNS427, CNS428, CNS429, CNS430 y CNS431). Cubría una matriz de forma irregular que contenía el } \\
\text { fardo de un infante (CNS432). El material cerámico corresponde a fragmentos de vasijas de los estilos Inca e } \\
\text { Ychma. }\end{array}$ \\
\hline 5 & - & $\begin{array}{l}\text { Capa de arena semicompacta. Sobre esta capa se depositaba el Elemento 3, estaba removida hacia el lado } \\
\text { (oeste) donde se encontraban concentrados los hallazgos de perros. }\end{array}$ \\
\hline 6 & - & $\begin{array}{l}\text { Apisonado disturbado por el depósito del Elemento } 3 \text { y el Contexto Funerario } 1 \text { (CNS432). Presentaba dos } \\
\text { posibles hoyos de poste. }\end{array}$ \\
\hline 7 & - & $\begin{array}{l}\text { Apisonado removido por el Contexto Funerario } 1 \text { (CNS432) y el Hallazgo CNS431. El material cerámico corres- } \\
\text { ponde a fragmentos de vasijas de los estilos Inca e Ychma. }\end{array}$ \\
\hline
\end{tabular}


Continuación de página anterior..

\begin{tabular}{|c|c|c|}
\hline Capa & Nivel / Elemento & Descripción \\
\hline 8 & 1 & $\begin{array}{l}\text { Apisonado con varias intrusiones (posibles hoyos de poste); la más grande (Elemento } 4 \text { ) corría perpendicular } \\
\text { al muro. El material cerámico corresponde a fragmentos de vasijas del estilo Ychma. }\end{array}$ \\
\hline 8 & Elemento 4 & $\begin{array}{l}\text { Intrusión alargada. Al retirar este elemento, se identificaron cuatro posibles hoyos de poste. Uno de ellos se } \\
\text { localizo al pie de la esquina del acceso, este habría servido para colocar una puerta, que sugiere que en un } \\
\text { momento la circulación hacia la PCR } 07 \text { fue bastante restringida y/o controlada. El elemento } 7 \text { se asocia a } \\
\text { este hoyo. }\end{array}$ \\
\hline 8 & Elemento 5 & Hoyo de poste. \\
\hline Estructu & ra de Adobes 1 & $\begin{array}{l}\text { Estructura de adobes de planta cuadrangular que estaría enmarcando el acceso a la plaza lateral de la PCR } 07 . \\
\text { Fue construida sobre un apisonado (capa 10). Su presencia dividió la excavacion en Lado Norte y Lado Sur. } \\
\text { Interiormente contiene varias capas o apisonados (Lado Sur). El Lado Norte, hace referencia a las capas que se } \\
\text { encontraron alrededor o al exterior de esta estructura. }\end{array}$ \\
\hline 8 & 2 - Lado Sur & $\begin{array}{l}\text { Apisonado arcilloso delimitado por la Estructura de Adobes } 1 \text {. En el se definieron dos posibles hoyos de } \\
\text { poste. }\end{array}$ \\
\hline 8 & 3 - Lado Sur & Apisonado arcilloso. Presento un elemento (Elemento 7) localizado cerca al acceso. \\
\hline 8 & 3 - Elemento 7 & $\begin{array}{l}\text { Elemento localizado alrededor del hoyo de poste localizado en la esquina del acceso. Se trata de un nivel de } \\
\text { relleno para reforzar uno de los parantes de la puerta del acceso. }\end{array}$ \\
\hline 8 & 2 - Lado Norte & $\begin{array}{l}\text { Apisonado. Tenía, por lo menos, tres hoyos de poste y de una concentración de cerámica (Elemento 6). El } \\
\text { material cerámico de este nivel corresponde a fragmentos del estilo Ychma. }\end{array}$ \\
\hline 8 & 2 - Elemento 6 & Concentración de cerámica y otros restos. El material cerámico corresponde a fragmentos del estilo Ychma. \\
\hline 8 & 3 - Lado Norte & Capa arcillosa de consistencia compacta en la que se superpone el Elemento 8. \\
\hline 8 & 3 - Elemento 8 & $\begin{array}{l}\text { Concentración de abundantes restos de moluscos y vertebras de pescado. El material cerámico corresponde } \\
\text { al estilo Ychma. }\end{array}$ \\
\hline 9 & Lado Norte & Apisonado. Presento una pequeña intrusión (Elemento 9). \\
\hline 9 & Elemento 9 & Intrusión pequeña que contenia restos óseos de un animal (mamifero). \\
\hline 10 & Lado Norte & $\begin{array}{l}\text { Apisonado sobre el que se construye la Estructura de Adobes 1. Estaría relacionado a la construcción del } \\
\text { muro de la calle (¿zanja de reforzamiento de la base?). El material cerámico corresponde al estilo Ychma. }\end{array}$ \\
\hline 10 & Elemento 10 & Concentración de carbones en la superficie del apisonado o capa 10. \\
\hline Estructu & ra de Adobes 2 & $\begin{array}{l}\text { Estructura de adobes cuadrangular considerada como un fogón. El interior contenía solo fragmentos de ado- } \\
\text { bes quemados; no se encontró ceniza. }\end{array}$ \\
\hline 11 & 1 - Lado Norte & $\begin{array}{l}\text { Superficie sobre la que se construye la Estructura de Adobes } 2 \text {. Se encontraba removida por la construcción } \\
\text { del muro de la calle, por estar cubierta con la capa } 10 \text { y por la presencia de tres instrusiones u hoyos (uno de } \\
\text { ellos cortaba a el Elemento } 13 \text { a la mitad). }\end{array}$ \\
\hline 11 & 1 - Elemento 11 & Posible hoyo de poste. Tenía una profundidad de $17 \mathrm{~cm}$. Intruía el nivel 1 hasta el nivel 2 de la capa 11. \\
\hline 11 & 2 - Lado Norte & $\begin{array}{l}\text { Capa de arena fina semicompacta con algunos restos materiales. Sobre ella se asienta el muro que delimita el } \\
\text { área de la calle Norte-Sur y la plaza lateral de la PCR } 07 \text {. }\end{array}$ \\
\hline 11 & 3 - Lado Norte & $\begin{array}{l}\text { Capa de arena fina, de consistencia semicompacta. Se le denominó Nivel } 3 \text { por la presencia de un par de } \\
\text { elementos, uno de los cuales (Elemento 13) estaba bastante removido y recortado por un hoyo de gran } \\
\text { dimensión registrado desde el nivel } 1 .\end{array}$ \\
\hline 11 & 3 - Elemento 12 & Intrusión pequeña de forma semicircular. \\
\hline 11 & 3 - Elemento 13 & Hoyo de poste. Todo su contorno interno estaba recubierto con barro. Contenia restos de madera (lúcuma). \\
\hline 12 & Lado Norte & Apisonado o nivel de uso anterior a la construcción de la Calle Norte-Sur. \\
\hline 13 & Lado Norte & Nivel de uso o apisonado anterior a la construcción al muro que delimita la Calle Norte-Sur y la plaza lateral. \\
\hline 14 & Lado Norte & $\begin{array}{l}\text { Capa de arena fina con regular cantidad de material cultural. También es anterior a la construcción de la Calle } \\
\text { Norte-Sur y la plaza lateral. El material cerámico, al igual que la capa 13, corresponde con el estilo Ychma } \\
\text { (algunos fragmentos del tipo Inciso-Punzonado). }\end{array}$ \\
\hline
\end{tabular}

Tabla 2: Cuadro resumen de la descripción estratigráfica del Pozo de Cateo 03

Table 2. Summary chart of the stratigraphic descriptions from Pozo de Cateo 03

unos $12 \mathrm{~cm}$ de ancho aproximadamente. Se encontraba en la esquina noroeste del cateo, al pie del muro, en una intrusión hecha en un apisonado (Capa 4). El fardo está conformado por dos capas de textiles de fibra de algodón y finalmente enrollado de forma horizontal y vertical con fibra de totora. Si bien se reconoció una sola técnica textil en los envoltorios, éstos pertenecían a tres tejidos distintos. Al interior se encuentra un pequeño can, un ejemplar de 3 a 5 semanas aproximadamente, en posición de cúbito lateral derecho, su pelaje es corto 


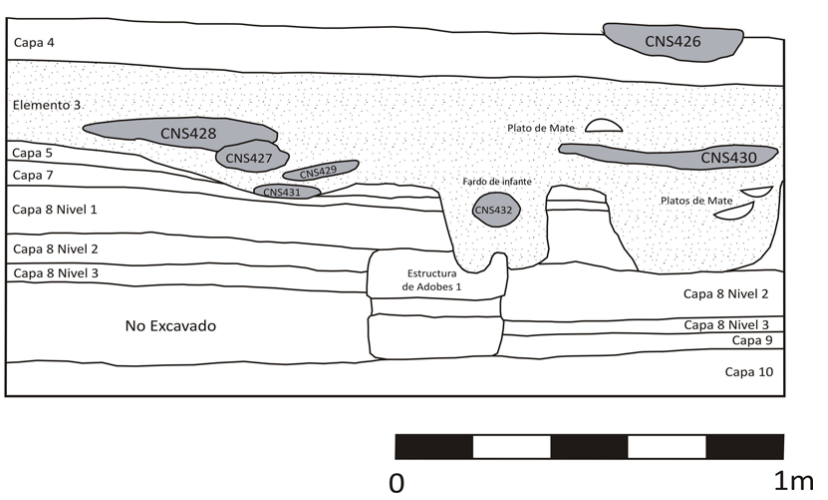

Figura 3: Corte Transversal del Pozo de Cateo 03 con distribución de los hallazgos.

Figure 3. Cross section of Pozo de Cateo 03 with distribution of findings.

de color marrón oscuro en la cabeza y lomo y de marrón amarillento en la región ventral.

Hallazgos CNS427, CNS428, CNS429, CNS430 y CNS431 Se trata de cinco canes momificados naturalmente, dos de los cuales están enfardelados. Provienen de una capa de basura secundaria (Capa 5-Elemento 3) que cubría una intrusión en cuyo interior se encontró un pequeño fardo de un infante -Hallazgo CNS432 (Figura 3). Si bien los hallazgos no tenían una orientación particular, parecían rodear el área donde se definió la intrusión. El material asociado nos sugiere que este evento formó parte de las últimas actividades realizadas en el Horizonte Tardío (1470-1533 d.C.) en la plaza lateral.

\section{Hallazgo CNS427}

Se trata de los restos de un can enfardelado, de 47 $\mathrm{cm}$ de largo por $25 \mathrm{~cm}$ de ancho aproximadamente. El envoltorio está formado por dos paños textiles hechos con fibra de algodón y cocidos uno con otro, es evidente el desgaste y rotura de los paños. Finalmente, el fardo fue amarrado con unas soguillas hechas de totora. No tenía una disposición particular dentro de la capa de donde proviene. Se ha podido determinar que los restos corresponden a un individuo adulto/joven, entre 12 a 16 meses. Se encuentra en posición de cúbito lateral derecho, tiene pelaje corto y de color marrón oscuro en el lomo (Figura 4).

\section{Hallazgo CNS428}

Conformado por los restos de un can enfardelado de 43 $\mathrm{cm}$ por $36 \mathrm{~cm}$ aproximadamente, ubicado muy cerca al hallazgo CNS 427. El envoltorio está formado por dos paños textiles hechos con fibra de algodón y cocidos uno a otro. Al igual que el Hallazgo CNS427, pareciera que estuvo amarrado externamente pues sobre el fardo se encontraron restos de soguillas hechas con fibra de totora. Así como los otros hallazgos, no tenía una orientación particular dentro del Elemento 3. Se ha podido determinar que se trata de un individuo joven que tenía entre seis

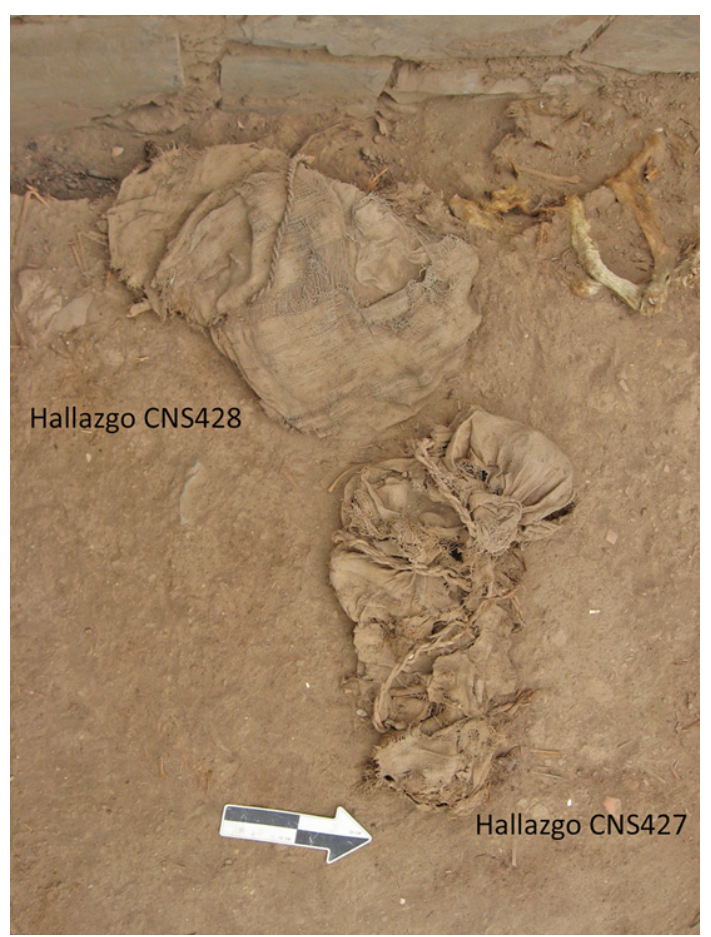

Figura 4: Hallazgos CNS427 y CNS428.

Figure 4. Findings CNS427 and CNS428.

a 12 meses aproximadamente. Tiene pelaje corto y de color marrón oscuro.

\section{Hallazgo CNS429}

Se encontraba al pie del muro. Se trata de los restos de un can momificado naturalmente, en posición de cúbito lateral derecho. No estaba cubierto por ningún tipo de envoltorio. Se encontraba removido por una intrusión registrada desde capas superiores (Elemento 2), por lo cual sólo se recuperó la mitad del cuerpo, a excepción del cráneo, costillas y vértebras cervicales y toráxicas. Se trata de un individuo joven, de seis a nueve meses aproximadamente, con $34 \mathrm{~cm}$ de altura (a la cruz) y $40 \mathrm{~cm}$ de largo aproximadamente. El pelaje es corto y de color marrón amarillento, la cola larga y en caída (Figura 5).

\section{Hallazgo CNS430}

Corresponde a los restos completos de un can momificado naturalmente, se encuentra en posición decúbito lateral derecho. Tampoco presentaba evidencia de haber estado cubierto por algún tipo de envoltorio. Se encontraba muy cerca del perfil Norte del cateo. No tenía una orientación particular dentro de la capa de donde proviene. Su buen estado de conservación ha permitido caracterizar y reconstruir el fenotipo de este conjunto de hallazgos. Es un individuo adulto/joven entre nueve a 18 meses aproximadamente, con $40 \mathrm{~cm}$ de altura aproximadamente (a la cruz) y $38 \mathrm{~cm}$ de largo. Las orejas son cortas, la cola larga y el pelo corto es de color marrón amarillento (en la región ventral y extremidades) y marrón oscuro (en el lomo o manto). 


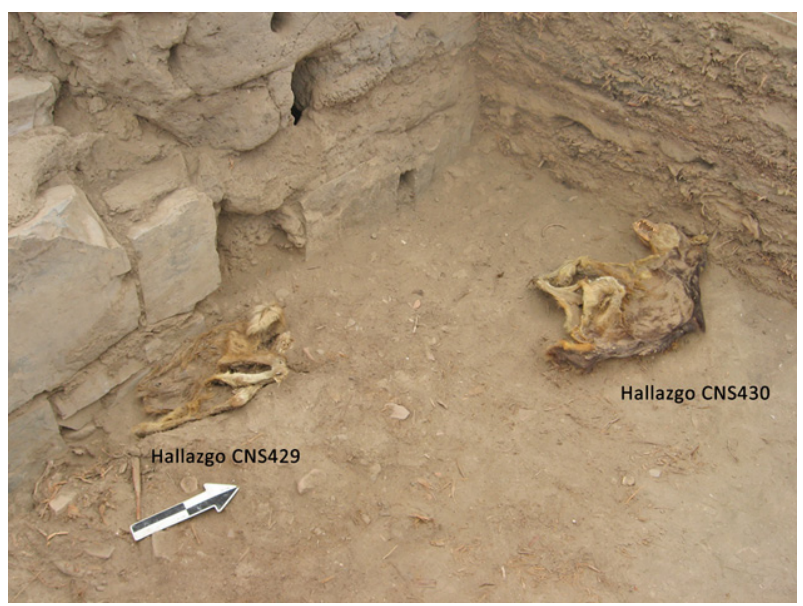

Figura 5: Hallazgo CNS429 y CNS430

Figure 5: Findings CNS429 and CNS430.

\section{Hallazgo CNS431}

Se encontraba a unos centímetros por debajo del hallazgo CNS429, por lo cual también fue afectado por una intrusión o remoción (Elemento 2). Son los restos de un can momificado naturalmente, en posición de cúbito lateral izquierdo. Estaba enfardelado, pero por la remoción sólo quedaron restos de los textiles entre sus patas delanteras y cabeza. El envoltorio estaba conformado por dos capas de textiles de algodón blanco. Entre sus patas delanteras se encontró un pequeño paquete que envolvía restos de pescado, hecho de un fragmento textil de algodón recortado de una prenda. Se trata de un cachorro que debía de tener entre tres a seis meses aproximadamente, de $22 \mathrm{~cm}$ de altura (a la cruz) y $32 \mathrm{~cm}$ de largo. La cola es larga, el pelaje es corto y de color marrón oscuro con algunas manchas de color marrón amarillento en las patas y en el lomo muy cerca a la cabeza (Figura 6).

En los hallazgos CNS426, CNS427, CNS428 y CNS431, los textiles envoltorios parecen no ser muy elaborados ni hechos ex-profeso para el enfardelamiento pues evidencian desgaste, recortes, falta de orillos, todo lo cual indica que provienen de otras piezas textiles $y$, probablemente, de uso distinto al mortuorio. La condición de los mismos ha facilitado y permitido la observación para la identificación y análisis zooarqueológico correspondiente. Hay que señalar que todos los hallazgos, a excepción del CNS426, tenían restos de pupas de insectos (sin identificar) que indicarían la exposición temporal de los mismos.

Como mencionamos líneas arriba, la capa de donde provienen estos canes cubría una intrusión de forma irregular, localizada en la esquina Noroeste del pozo de cateo, en la cual se encontró un pequeño fardo alargado de $54 \mathrm{~cm}$ por $15 \mathrm{~cm}$ aproximadamente, y que corresponde a un infante. Para hacer esta cavidad, cortaron varias capas también relacionadas al uso de la plaza, alcanzando una profundidad de $20 \mathrm{~cm}$ aproximadamente (Figura 7).

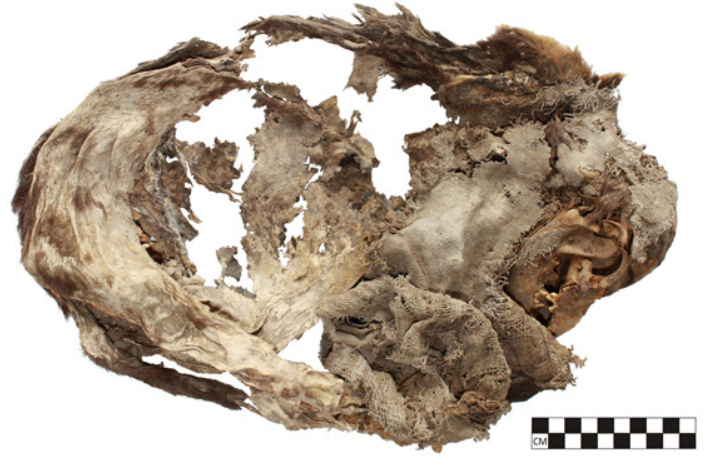

Figura 6: Hallazgo CNS431. Obsérvese que entre sus extremidades tiene un pequeño paquete "ofrenda".

Figure 6. Finding CNS431. Note that there is a small "offering" packet between its extremities.

Uno de los extremos del pequeño fardo alargado se encontraba algo removido, desde el que se pudo observar parte del cráneo y cuero cabelludo correspondiente a un infante, así como que sus restos estarían envueltos por lo menos con cuatro capas de tejidos de algodón, algunos decorados (listados y con diseños cuadriculados), sólo su rostro fue cubierto con algodón natural blanco y pardo. Estos tejidos parecen haber sido hechos ex-profeso para el enfardelamiento ya que se encuentran en buen estado, con orillos o bordes completos y sin evidencia de desgaste. Las futuras labores de desenfardelamiento de los restos de este individuo nos develarán más información sobre su edad, causa de muerte y otros datos que nos permitan correlacionarlos con los canes asociados a su enterramiento.

La asociación entre entierros humanos y canes es recurrente en el Santuario de Pachacamac, principalmente durante el Horizonte Tardío o época Inca. Las investigaciones de Paredes y Franco (1984) y Peter Eeckhout (2004b)

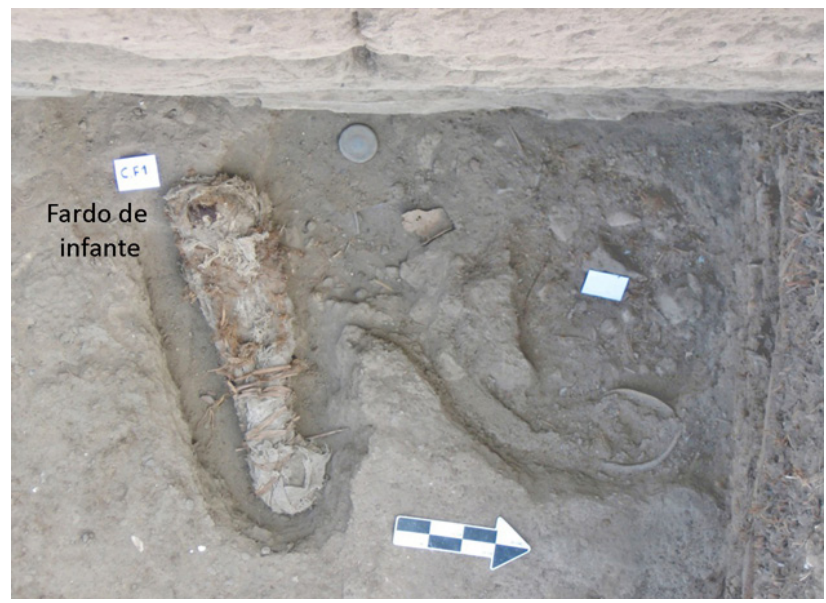

Figura 7: Detalle de planta de la intrusión donde se encontró el fardo de un infante (Hallazgo CNS432).

Figure 7. Intrusion floor where the infant bale was found (finding CNS432). 
reportan estos contextos funerarios como intrusivos en la PCR 03 y al pie del Templo Viejo y el Templo Pintado, donde los canes "no se enterraron dentro de las estructuras funerarias de personas, sino al lado, en la parte superior de la estratigrafía" (Eeckhout 2004b:26).

\section{Los canes de Pachacamac: Hallazgos arqueológicos en el santuario y en la costa peruana}

En el Santuario de Pachacamac otros investigadores han reportado contextos con presencia de canes como se detalla a continuación. Sin embargo, en esta oportunidad la participación de especialistas en los análisis biológicos y zoológicos permite confirmar su identificación a nivel de género y especie.

Max Uhle realizó el primer reporte sobre hallazgos de tres canes en el santuario. Dos de ellos se hallaron en un antiguo cementerio ubicado en la primera terraza del Templo del Sol, eran semejantes al bulldog y se encontraban al lado de ceramios y textiles de estilo Inca. Por su buen estado de conservación los identificó como Canis Ingas molosoides Nohring y los consideró perrosInca traídos de la sierra. Uno de ellos tenía un pelaje de color negruzco y el otro era manchado de amarillo y castaño. El tercero era un espécimen de perro pastor que denominó Canis Ingas pecuarius, el cual fue "hallado en las tumbas del Templo del Sol; de color amarillento y rojizo-castaño" (Uhle 2003[1896]: 328-330).

Paredes y Franco (1989) realizaron excavaciones entre el Templo Viejo y el Templo Pintado donde encontraron varios entierros disturbados, a pesar de ello pudieron establecer que los entierros databan del Intermedio Tardío (1100-1470 d.C.). En una de las cuadrículas de excavación (N5414) hallaron los restos de un can muy cercanos a los restos de un entierro humano; por la proximidad consideraron que habrían formado parte del mismo contexto. Los restos corresponden a un perro adulto dispuesto en forma extendida (cúbito lateral), de unos $40 \mathrm{~cm}$ de largo, cráneo mesocéfalo, con un particular desgaste de los molares debido a una alimentación

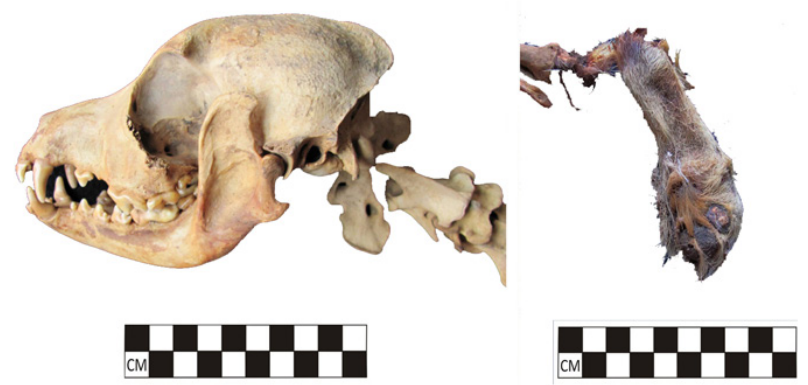

Figura 8: Restos del can procedente de la excavación entre el Templo Viejo y el Templo Pintado. Nótese que aún conserva parte del pelaje color marrón amarillento.

Figure 8. Dog remains from the excavation between Templo Viejo and Templo Pintado. Note that parts of its yellowish-brown fur are still kept. probablemente basada en granos secos, el pelaje es corto de color marrón veteado con un color amarillo pálido (Figura 8).

Hasta el momento, hallazgos similares a los nuestros (dentro de los conjuntos piramidales o PCR) provienen de diferentes excavaciones llevadas a cabo en distintos sectores de la PCR 03 (ver Eeckhout 1995:69, Figura 3), por diferentes investigadores desde la década de 1980.

Paredes y Franco (1984) excavaron en el muro de una plaza pequeña adyacente al volumen piramidal de la PCR 03 que denominan Frente Este o Frente C. En ese lugar encontraron los restos de tres canes envueltos con textiles de algodón, con un característico pelaje corto, lacio y de color amarillo y marrón. Por el material cerámico recuperado, estos contextos pertenecen a la última ocupación de la PCR que data del Horizonte Tardío (1470-1533 d.C.). El primero se encontró en un área cercana a la esquina norte del Frente $C$, pero su asociación e interpretación no pudo ser definida por la cantidad de escombros y basura. El segundo se hallaba al interior de un forado en el muro y sobre el cuerpo estaban colocados los restos de dos cuyes (Cavia porcellus). El tercero estaba asociado a un entierro humano disturbado que se encontraba en la base erosionada del muro.

Estos investigadores interpretaron los hallazgos como ofrendas que recibieron un tratamiento mortuorio (enfardelamiento) debido a que eran animales muy estimados. También plantearon la idea de que se trataba de perros domesticados (Canis familiaris) y que en el Horizonte Tardío (1470-1533 d.C.) se podían encontrar en cada pirámide. Tal idea surge de las evidencias que se encontraron en la PCR 02, una de ellas fue el hallazgo de dos perritos gemelos hechos de cerámica en el ingreso principal y la otra evidencia fue la reutilización de un depósito como un "corral para la crianza" de este animal, aunque han sido cautelosos en la identificación de éste como Canis familiaris (Paredes y Franco 1984:13).

Eeckhout (1995) realizó excavaciones en la Plaza I de la PCR 03 y definió dos ocupaciones para los periodos tardíos (Ychma e Inca). De esta área reporta el hallazgo del esqueleto completo de un perro (Entierro 1) y los restos bien conservados de una zorra (Entierro 4), ambos tenían restos de un textil sobre la cabeza. El primero se encontró en el lado suroeste de la plaza y contemporáneo a una tumba colectiva con restos humanos disturbados, por lo que señala que "se trataría de un perro guardián de la misma" (Eeckhout 1995:101). El segundo hallazgo se encontró en un relleno pegado a la base del muro que configura la Plaza I. Precisa que se trata de una zorra de pelo largo, espeso y de color rojizo (rojo-anaranjado) (ver Eeckhout 1995:94, Figura 26). Aunque no hay una identificación certera desde un inicio, en una publicación relativamente reciente se señala que estos dos hallazgos pertenecen a Canis familiaris y Canis molosoides 
(Eeckhout 2004b). Asumimos que con ello se deja de lado la referencia al Entierro 4 como correspondiente al de una zorra.

Existe la referencia sobre la presencia de zorros en el santuario, como lo reseña María Rostworowski:

\begin{abstract}
"Pachacamac...era tan estimado este lugar que sólo se permitía el acceso de señores y sacerdotes que sacrificaban zorros a manera de ofrendas (Cieza de León 1941 [1553], Cap. L). Una representación de este animal existía en Pachacamac. Era una zorra muerta cerca de la puerta del mismo santuario y era llamada Tantanamoc" (Rostworowski 2009:44-45).
\end{abstract}

Sin embargo, el hallazgo de zorros -sacrificados o no- en el registro arqueológico del santuario no ha podido ser comprobado hasta el momento.

En el 2009, durante las labores de Conservación de Emergencia ejecutadas por el MSPAC ${ }^{5}$, se intervino un segmento periférico (Unidad 12) del muro de la Plaza I de la PCR 03. En este punto se definieron dos ocupaciones. En la primera se habría construido el muro y se le asocia a cerámica de estilo Ychma, la segunda corresponde a un basural concentrado al pie del muro en el que "se resalta la presencia de cerámica Inca y el depósito de ofrendas" (Pozzi-Escot y Chávez 2009:33). Estas ofrendas corresponden a dos Canis familiaris (Fardo 1 y 2) de dos a cuatro semanas de vida, fueron envueltos con textiles de algodón y amarrados externamente con soguillas de fibra vegetal (Figura 9). No hay lesiones que sugieran posibles causas de muerte, su pelaje es corto y de color amarillo y marrón-rojizo del que se recuperaron pulgas y garrapatas en diversos estadios de desarrollo o etapas de crecimiento.

Eeckhout y su equipo en las excavaciones en el patio

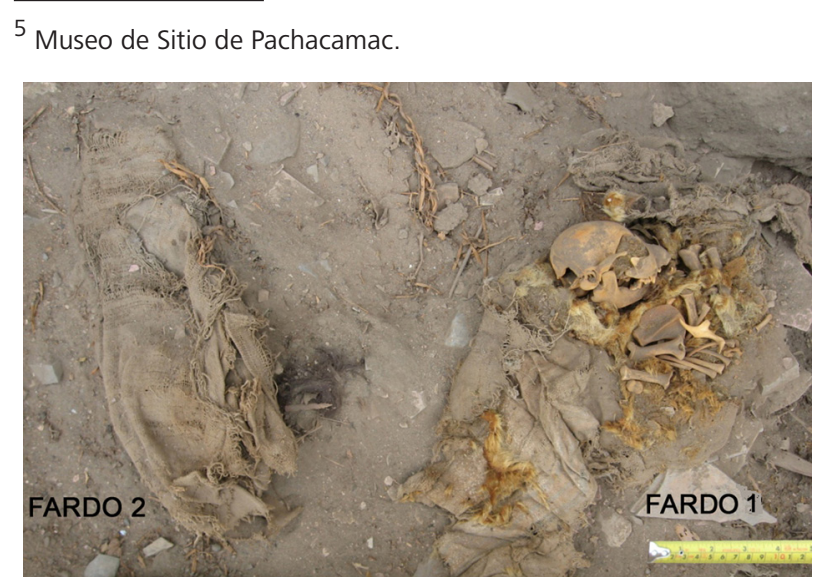

Figura 9: Hallazgos de Canis familiaris encontrados en la PCR 03 durante los trabajos de conservación del MSPAC del 2009.

Figure 9. Findings of Canis familiaris in PCR 03 during the MSPAC conservation work in 2009. trasero de la PCR 13, registraron el hallazgo de restos de animales, entre ellos el de un can (Entierro 92) asociado al entierro de niños y adultos (ver Eeckhout 2008:17, Figura 6; 99, Figura 74). El perro se encontraba en un nivel superior a los entierros humanos. Este contexto sería parte del cementerio cercano al Templo de Pachacamac o Templo Pintado, pues se depositaron previamente a la construcción del muro Este que conforma el límite de la PCR 13 con el recinto colindante conocido como Sala Central (Eeckhout 2008). Sobre este hallazgo, que cronológicamente se ubicaría en el Intermedio Tardío (1100-1470 d.C.), no se tienen mayores referencias anatómicas que permitan caracterizarlo.

En la PCR 07B ${ }^{6}$ se hallo un cánido ${ }^{7}$ (Entierro 93) y restos de cuyes (Cavia porcellus). Los hallazgos se encontraron al pie de la rampa principal, en la articulación de ésta con el patio. El cánido estaba enterrado dentro de un hoyo hecho en el primer piso de la PCR 07B, el cual "se preparó para las ofrendas" (Eeckhout 2008:51). Cabe señalar que en este caso, el hallazgo no se asocia aparentemente a entierros humanos sino que estaría relacionado con la construcción o cambio de función de la PCR en el Horizonte Tardío (1470-1533 d.c.).

Eeckhout (2004b) sugiere que los canes fueron depositados al final de los ritos funerarios y que, posiblemente, fueron sacrificados en ese momento. Si bien, es recurrente la asociación entre sepulturas humanas acompañadas de Canis familiaris, aún no se cuenta con las evidencias que precisen las causas de muerte de los animales. Algunos de los análisis practicados en nuestros recientes hallazgos permiten dilucidar algo sobre este tema, pero todavía no existe la certeza sobre el sacrificio.

Los canes de Pachacamac parecen diferenciarse de otros encontrados o representados en distintos periodos y regiones de la costa peruana. Por ejemplo, en la Costa Norte y Sur durante el Intermedio Temprano (200600 d.C.), los Moche y los Nazca representaron canes pequeños de cola enroscada sobre el lomo, pelo corto y de color blanco con grandes manchas oscuras o negras (ver Donan y MacClelland 1999:89, Figura 4.29).

En la Costa Central durante el Intermedio Tardío (11001470 d.C.), en los valles de Chancay y Huaura, se encontraron vasijas del estilo Chancay que representan canes sin pelo. Estos canes están caracterizados por la ausencia de pelo y de hasta 20 a 22 piezas dentarias (ver Weiss 1976:41, Lam. III).

En la Costa Sur, en Ilo, se excavaron canes en excelente estado de conservación, conocidos como "perros pastores Chiribaya" que datarían del Intermedio Tardío (1100-

\footnotetext{
${ }^{6}$ La denominación corresponde al volumen piramidal central del conjunto arquitectónico. Ver plano del conjunto piramidal.

7 Sólo en los casos que no se tenga la certeza sobre el género y especie, se les denomina a nivel de familia.
} 
1470 d.C.). Son de talla menor, con el cuerpo más largo que alto, orejas semicaídas, patas cortas y pelo largo de color amarillento o blanco en casi todo el cuerpo. Un can con características similares fue encontrado en un cementerio localizado en la península de Paracas pero dataría del periodo Nazca o Intermedio Temprano (ver Engel 1987:125, Figura III-19b).

Esta comparación nos permite señalar que los canes de Pachacamac parecen no tener relación directa con ninguno de los tipos de canes encontrados en otros sitios costeños, debido a las diferencias de forma de cuerpo, pelaje y color. Mientras que los hallazgos de canes reportados en el santuario, tanto por su procedencia como por sus características anatómicas, nos sugieren una cierta similitud con los encontrados en el acceso a la PCR 07. Un estudio comparativo más amplio entre estos diversos hallazgos de canes nos permitirá desarrollar y ampliar nuestra visión sobre ellos.

\section{Metodología de identificación: Análisis realizados y reconstrucción fenotípica}

Para el estudio de los canes, hemos realizado una serie de exámenes comparativos para identificar aspectos como especie, edad, patologías óseas, traumas, altura a la cruz, peso corporal y tipo de cráneo. En esta etapa de nuestras investigaciones, no hemos considerado el desenfardelamiento por lo que el estudio de los restos se ha realizado aprovechando la condición en que se encontraron los envoltorios (con desgastes y roturas).

La identificación de género y especie, edad, así como el análisis forense de los restos fueron realizados utilizando una colección de material comparativo de individuos modernos y fuentes bibliográficas especializadas.

El examen forense se ha realizado para determinar patologías óseas y traumas pre o perimortem, que podrían indicar las posibles causas de muerte. Consideramos que en el caso de encontrar fracturas en el cráneo o señales de corte en las vértebras, éstos podrían ser indicadores de muerte por sacrificio. El empleo de placas radiográficas ayuda en este análisis para examinar las condiciones en que se encuentran los animales enfardelados, por ahora sólo ha podido ser empleada en el Hallazgo CNS426 ${ }^{8}$.

La edad fue determinada teniendo en cuenta el tamaño y estado de fusión de las epífisis de los huesos, en los dientes se observó si éstos eran deciduos ${ }^{9}$ o permanentes (Dyce et al. 2004), así como el grado de desgaste en incisivos, premolares y molares. Considerando estos datos, hemos establecido un rango de edad para los

\footnotetext{
8 En este caso la exposición de la toma fue de 60 Kv / 30 ma / 0.08 segundos, realizada en un equipo Marca Soyee Modelo SY-31-100P.

9 Deciduos son dientes provisionales que se van reemplazando por dientes permanentes; esto se completa a los 7 meses con lo que al animal se reconoce como un individuo adulto joven.
}

\begin{tabular}{ll}
\hline Cachorro & $1-6$ meses \\
Joven & $6-12$ meses \\
Adulto/Joven & $12-18$ meses \\
Adulto & 18 meses en adelante \\
\hline
\end{tabular}

Tabla 3: Rango de edad en canes.

TTable 3. Age range of the dogs.

individuos (Tabla 3).

El cálculo aproximado de la altura (a la cruz) se obtuvo considerando la sumatoria de las medidas de las falanges, radio-cúbito, húmero y escápula ${ }^{10}$. Para el largo del cuerpo se consideró la medida en centímetros de la distancia desde el pecho hasta la base de la cola.

El peso corporal fue obtenido en base al tamaño aproximado del Hallazgo CNS430, comparado con un perro adulto vivo de similares características físicas.

Para caracterizar el tipo de cráneo, se empleó la propuesta de Dyce y colaboradores (2004), que realizaron una tipología basada en la forma y tamaño del cráneo en canes: dolicocefálica, mesocefálica y braquicefálica (ver Dyce et al. 2004:398, Figura 11-1).

La presencia de pupas de insectos asociadas a cada uno de los hallazgos nos indica que los animales estuvieron expuestos a la intemperie por algún tiempo; sin embargo, queda aún por realizar el análisis de entomología forense para identificación de la(s) especie(s) de insecto(s) y demás implicancias.

La reconstrucción fenotípica del conjunto de hallazgos de canes analizados se ha realizado mediante la observación directa de los mismos. Las características específicas corresponden al ejemplar mejor conservado: Hallazgo CNS430. El primer paso para ello fue la realización de bocetos realizados por el artista plástico Luis Tokuda, los cuales están basados en las medidas tomadas de los huesos, el tipo de cráneo y tipo de pelaje. Finalmente, la imagen fue digitalizada y editada con el programa Adobe Photoshop CS3, donde se trabajaron por capas para retocar cada uno de sus detalles como la intensidad de color, el tamaño de ojos, cola y orejas (Figura 10).

En el futuro, otros análisis más específicos (i.e., estudios isotópicos, entomológicos, etc.) nos permitirán conocer las condiciones de vida de los canes, su procedencia, causa de muerte, etc.

\section{Resultados y conclusiones preliminares}

El conjunto de hallazgos procedentes de nuestras excavaciones en el acceso a la PCR 07, corresponde a los

\footnotetext{
10 Medida tomada de uno de los miembros anteriores.
} 


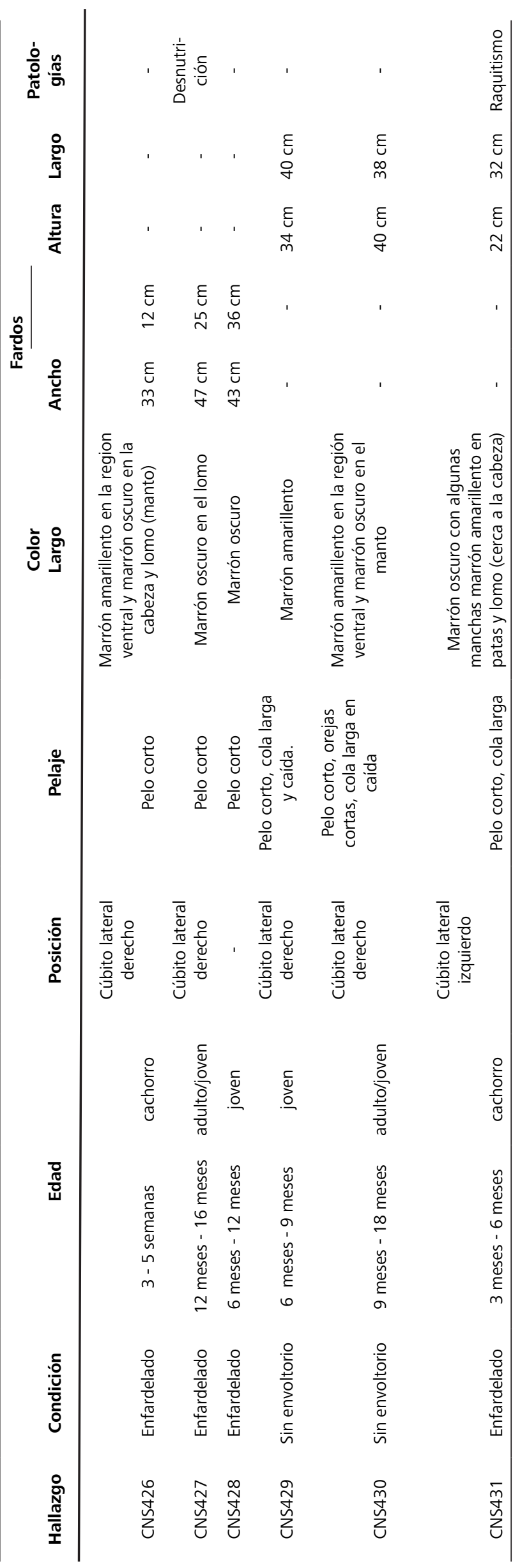

Tabla 4: Cuadro resumen de las características anatómicas de los hallazgos del Pozo de Cateo 03.

Table 4. Summary chart of the anatomical characteristics of findings from Pozo de Cateo 03.

restos de seis cánidos identificados como Canis familiaris, conocido comúnmente como perro doméstico.

El rango de edad se encuentra entre las tres semanas a 18 meses de vida, correspondientes a dos cachorros, dos jóvenes y dos adultos/jóvenes (Tabla 4).

Las principales características corporales evidencian que eran canes de talla mediana, de 38 a $42 \mathrm{~cm}$ a la cruz, con estructura ósea rectangular del cuerpo y miembros; con un peso corporal entre 12 y 14 kilos aproximadamente. El pelo es corto, de color marrón amarillento en extremidades y región ventral del cuerpo; y de marrón oscuro como chocolate en el manto o lomo. Sólo el hallazgo CNS429 presenta color marrón amarillento en todo el cuerpo. La cola no estaba enroscada, y pueden haber tenido una caída hacia los miembros posteriores, con una ligera curvatura hacia arriba del tercio final de la cola (Figura 11).

La relación de largo de cuerpo y patas, con altura a la cruz, hacen una estructura de cuerpo rectangular, semejante al promedio de cualquier perro actual; no son individuos de patas cortas, como los canes Chiribaya estudiados por Guillen, o como el encontrado en Paracas o como los canes representados por los Moche y Nazca en su cerámica.

El examen forense practicado indica que ninguno de los canes tenía traumas o lesiones que puedan relacionarse a muerte traumática y/o por sacrificio del animal. A pesar que sólo contamos con la placa radiográfica de un ejemplar enfardelado (Hallazgo CNS426), en ella no se observa ningún tipo de lesión o fractura en los huesos largos de extremidades, costillas o cráneo (Figura 12).

Deberemos concluir con nuestro estudio sobre este conjunto de canes para determinar las causas de muerte. Está pendiente el empleo de placas radiográficas de los canes enfardelados para evaluar si tuvieron lesiones y el análisis de una muestra de los órganos para ver si fueron envenenados o no. A pesar de ello, de forma preliminar, podemos señalar que la causa de muerte de todo este grupo de canes fueron naturales y/o enfermedades (¿virales?) relacionadas posiblemente a las condiciones de vida en el santuario o fuera de él, razón por la cual no alcanzaron la adultez.

Sólo en dos de ellos se identificaron patologías óseas. Uno de ellos es el Hallazgo CNS431, se trata de un cachorro entre tres y seis meses que presenta las epífisis distales de las costillas dilatadas a manera de copa y que forman un "rosario raquítico", lo cual es señal de raquitismo en 

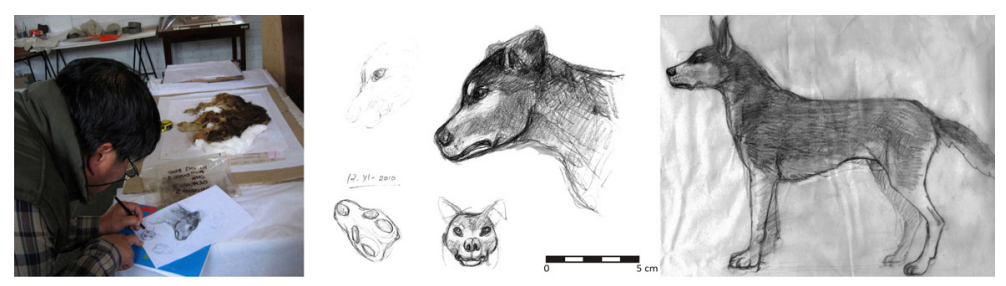

Figura 10: Proceso de reconstrucción fenotípica mediante dibujos y toma de medidas. Realizado por Luis Miguel Tokuda.

Figure 10. Phenotypic reconstruction process through drawings and measurements, by Luis Miguel Tokuda. cachorros, estado que permanece hasta la adultez (Smith y Jones 1962:722-723). El otro es el Hallazgo CNS427, se trata de un adulto/joven entre 12 y 16 meses que presenta evidencias de un crecimiento óseo asimétrico en una vértebra dorsal que podría relacionarse a problemas de desnutrición (Figura 13).

Algo interesante de resaltar es el buen estado de conservación en el que se encontraron los hallazgos debido a que permanecieron enterrados en las condiciones áridas típicas del desierto costeño del país. El cuerpo de los perros estuvo en contacto directo con materiales secos como arena y tierra, ello ha producido un desecamiento de los líquidos corporales que se movilizaron hacia los materiales que los rodearon, originando el estado de momificación en el que fueron encontrados.

La presencia de las pupas de insectos asociadas a los restos óseos indica que los canes no fueron enterrados luego de ocurrida la muerte; por el contrario, éstos debieron estar expuestos varios días antes de realizarse la sepultura. En el futuro, los análisis de entomología forense nos brindarán más información como la identificación de los posibles traslados del cuerpo, las características de las zonas de procedencia, etc.

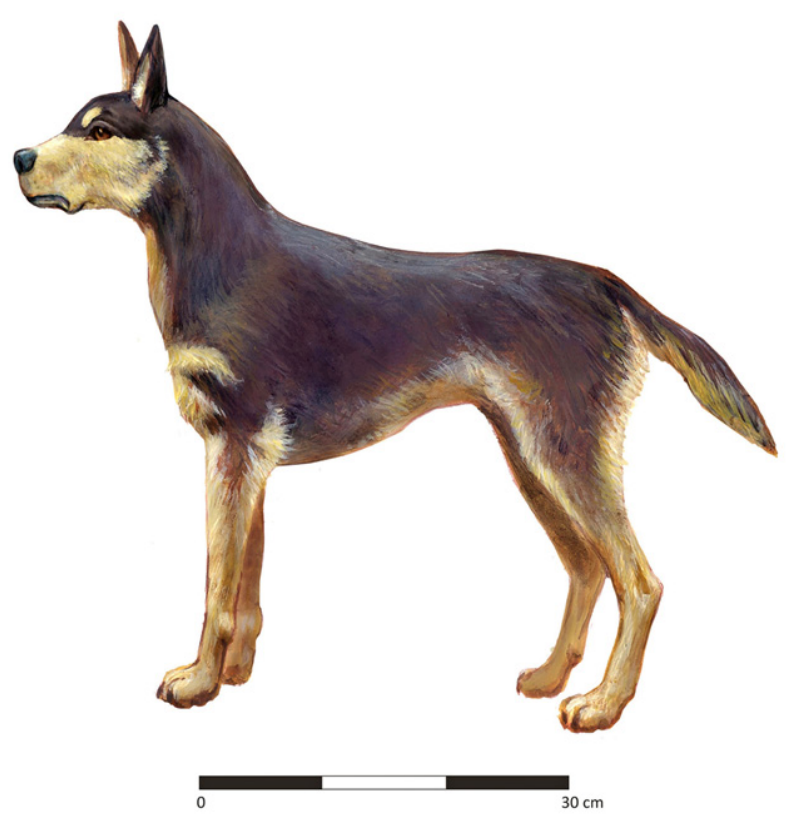

Figura 11: Reconstrucción fenotípica del conjunto de hallazgos, basado en un individuo adulto/joven o Hallazgo CNS430.

Figure 11. Phenotypic reconstruction of the sample of findings, based on an adult/young individual or Finding CNS430.
En nuestras excavaciones en la PCR 07 hemos notado que no hay ninguna norma de enterramiento de los canes, podían haber sido enfardelarlos o no. El tratamiento mortuorio indica que el enfardelamiento no estaba previsto, ya que los textiles son piezas reutilizadas y no se elaboraron ex-profeso para ser usadas como envoltorios de los canes $^{11}$.

Solo en el caso del Hallazgo CNS426 no se ha podido establecer una asociación con un entierro humano, quizá debido a las características y objetivos de nuestra excavación. Las dimensiones del Pozo de Cateo 03 fueron de $2 \mathrm{~m} \times 2 \mathrm{~m}$, lo que probablemente impidió que pudiéramos encontrar cualquier asociación, ya que el hallazgo se encontraba al extremo del cateo. La evidencia de que podemos encontrar más de estos hallazgos en la plaza lateral de la PCR 07, es la observación en el perfil norte de la excavación de restos de otro perro momificado (columna vertebral) al costado de un pequeño fardo (¿humano?).

\footnotetext{
11 María Luisa Patrón, conservadora textil del Museo de sitio de Pachacamac nos ayudó en la identificación de las técnicas textiles de los envoltorios de los canes como el fardo del infante.
}

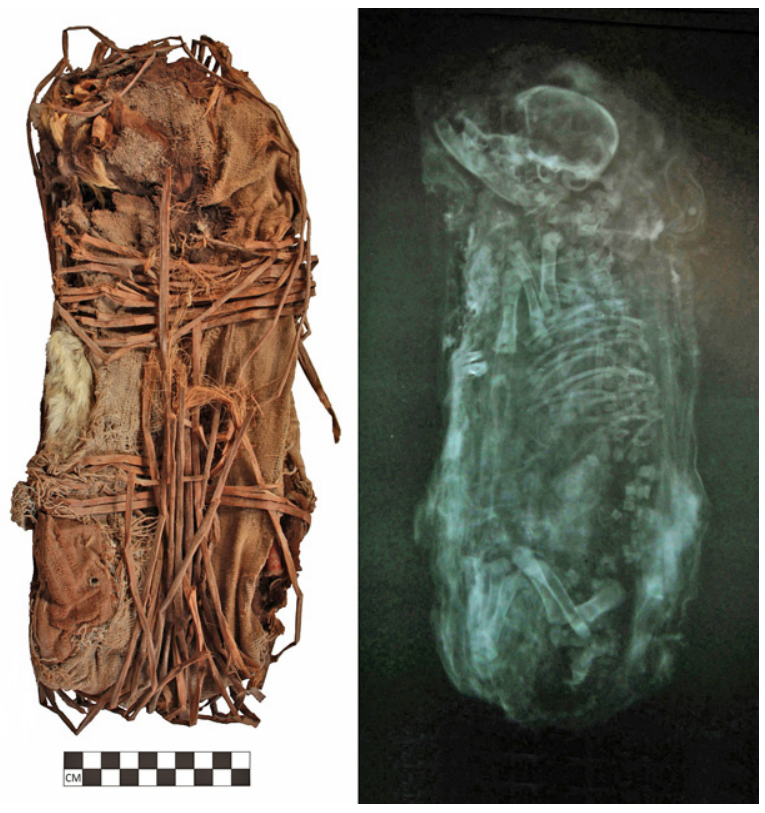

Figura 12: Imagen de Hallazgo CNS 426 con su correspondiente placa radiográfica. Obsérvese que es notorio que los huesos están intactos (sin fracturas), sin fusionar y aparentemente hay restos de algunos órganos en la región ventral (¿hígado?).

Figure 12. Image of Finding CNS426 with its radiographic film. Note that bones are intact (not fractured), not fussed; there seem to be remains of some organs (liver?) in the ventral region. 

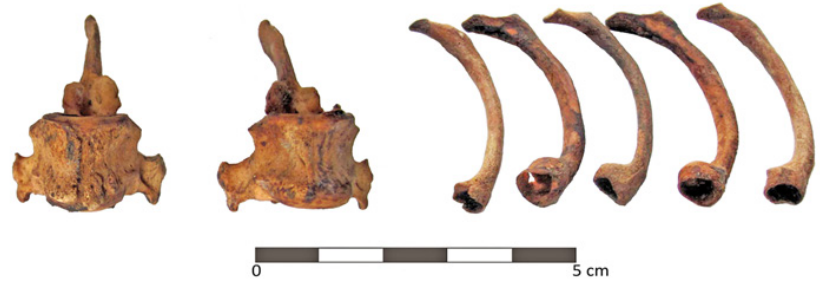

Figura 13: A la izquierda: Vertebras dorsales, a la izquierda se observa el crecimiento óseo asimétrico del cuerpo de una de ellas (Hallazgo CNS 427). A la derecha: Epífisis de costillas dilatadas en forma de copa (Hallazgo CNS 431).

Figure 13. To the left: dorsal vertebrae; to the left we observe asymmetry in bone in relation to the body of one of the findings (Finding CNS427). To the right: epiphysis of dilated ribs forming a cup (Finding CNS431).

\section{Comentarios finales}

Los hallazgos de canes procedentes de diferentes excavaciones en el Santuario de Pachacamac comparten, por lo general, ciertas características básicas en cuanto a la morfología craneal, aunque se encontraron ciertas diferencias con respecto al Entierro 4 reportado por Eeckhout (2004b), y que parece ser similar a las descripciones de los hallazgos de Uhle (2003[1896]) en el Templo del Sol.

En efecto, los hallazgos en estudio son de cráneo mesocéfalo, como todo el conjunto proveniente del santuario, y sólo el denominado Entierro 4 es de cráneo braquicéfalo, es decir se nota un acortamiento de la mandíbula expuesto por el desgaste de los caninos inferiores con el tercer incisivo de la arcada dentaria superior, configurando así un cráneo más ancho y pesado, con mayor masa muscular y fuerza de mordida.

El tamaño y color (aun considerando las combinaciones y matices de los colores mencionados) del pelaje de los canes en el santuario es similar, exceptuando el del Entierro 4, que presenta mayor longitud y densidad de pelaje, además de tener un color marrón oscuro en la mayor parte del cuerpo, con amarillo-naranja en los miembros y pecho.

El pelaje muestra una diferencia notable pues los individuos excavados en la PCR 07 son de pelo corto ${ }^{12}$, lo cual indicaría que son animales que vivían o se adaptaron a un clima propio de la costa, mientras que el individuo braquicéfalo (Entierro 4) es de pelo largo y de mayor densidad, lo cual indica una mejor adaptación a climas fríos y se relacionaría quizás a una variedad propia de la sierra.

Se conoce que tanto en la Costa Norte y Sur peruana, para el periodo Intermedio Temprano (200-600 d.C.) e

\footnotetext{
12 Hasta la fecha no se han reportado individuos sin pelo
}

Intermedio Tardío (1100-1470 d.C.), se representaron y criaron canes con características que difieren tanto entre ellos como con los encontrados en Pachacamac. Por ello, podemos señalar que el fenotipo de canes estudiado, al parecer, fue bastante popular en el santuario y particular de la Costa Central en los periodos prehispánicos tardíos.

La importancia de estas evidencias hace necesario un estudio más detallado tanto de los restos de canes excavados en el santuario como los de otros sitios del valle de Lurín y de la Costa Central, para lograr proponer la existencia de un tipo de perro costeño prehispánico tardío característico de la zona, que no guarda relación o desciende necesariamente de los perros representados en la cerámica Moche, Nazca, Chancay y los canes Chiribaya momificados.

Si bien aún no es clara la función que cumplieron los conjuntos de PCR, previa a la ocupación Inca del santuario, las evidencias parecen indicar un uso de carácter público relacionado a la producción y/o control interno del santuario. Bajo el control Inca se habría incrementado la fama y el prestigio del oráculo, reflejado en el aumento del flujo de "peregrinos", en la construcción de importantes edificaciones como el Templo del Sol en un lugar privilegiado y en la reutilización de la infraestructura preexistente como las calles y las PCR. Estas últimas fueron reutilizadas para el enterramiento de personas que corresponderían quizás a devotos que se encontraban en peregrinaje al santuario; los enterramientos fueron acompañados constantemente por canes y varios objetos de valor (vasijas, alimentos, etc.).

Es claro que los canes no tuvieron un tratamiento mortuorio muy elaborado. Por el momento, sabemos que no tuvieron una muerte violenta; futuros análisis físicos/ químicos nos ayudaran a determinar sus condiciones de vida y las causas reales de su muerte. A pesar de esto, su presencia como "ofrendas" es importante y preferentemente como "acompañantes" en la sepultura de los peregrinos dentro del santuario durante la ocupación Inca.

La idea de los perros como "acompañantes" o "guías en la otra vida" está presente en una referencia recogida del Padre Arriaga, extirpador de idolatrias del Perú del siglo XVII, que señala "que los muertos van a la tierra del silencio pasando por un puente de palos y llevados por perros negros, que en algunas partes los crían para ese fin" (Citado por Weiss 1976:43).

Hasta ahora no hemos podido encontrar referencias o indicadores de que el perro fuera un animal de culto o específicamente para sacrificios, pero si parecen haber formado parte de las ceremonias relacionadas a la petición del agua, realizadas bajo la presencia de la luna o en el mes lunar cuando escasea el agua (Hocquenguen 2005). Referencias del siglo XVII de Guaman Poma y 
Garcilaso de la Vega, señalan que en estas ceremonias los Incas amarraban y golpeaban a sus llamas y perros en las plazas, mientras que ellos y sus hijos lloraban o hacian ruidos con caracoles, tambores y otros instrumentos. Con ello, buscaban atraer la atención de la luna para que se les concediera la presencia del agua. Esta relación entre perro y la luna, según Garcilaso era "por cierta fabula que ellos contavan, decian que la luna era aficionada a los perros, por cierto servicio que le havia hecho, y que oyendolos llorar havria lastima dellos" (Ver Hocquenghen 2005; Weiss 1976).

Como vemos el estudio de los canes de Pachacamac está todavía en una etapa inicial, todavía nos queda por profundizar nuestros análisis y referencias a nivel temporal y territorial de escala local y regional, que nos permita entender sus características y el rol que tuvieron dentro de las sociedades que peregrinaban a Pachacamac.

Lurín, 4 de Noviembre 2011

\section{Agradecimientos}

A María Luisa Patrón, conservadora textil del Museo de Sitio de Pachacamac. A Lic. Sonia Quiroz Calle. A Arq. Carmen Rosa Uceda. A Luis Miguel Tokuda Fujita quien hizo la reconstrucción fenotípica de los canes. Al Dr. Héctor Guzmán Iturbe de la Clínica Veterinaria "Las Garzas", quien nos apoyó con las radiografía de uno de los fardos.

\section{Bibliografía}

Donan, C. y D. MacClelland. 1999. The Classic Period. En Moche Fineline Painting its Evolution and its Artists, Capítulo 4, pp. 75-138. UCLA - Fowler Museum of Cultural History / University of California. Los Ángeles.

Dyce, K., W. Sack y C. Wensing. 2004. Cabeza y región ventral del cuello de los carnívoros. En Anatomía Veterinaria, Capítulo 11, pp. 398-411. Traductores: E. Rodríguez y J. Camón. McGraw-Hill Interamericana. México.

Eeckhout, P. 1995. Pirámide con rampa $N^{\circ} 3$ de Pachacamac, Costa Central del Perú. Resultados preliminares de la primera temporada de excavaciones (zona 1 y 2). Boletín del Instituto Francés de Estudios Andinos 24 (1): 65-106.

Eeckhout, P. 2004a. La Sombra de Ychsma. Ensayo introductorio sobre la Arqueología de la Costa Central del Perú en los Periodos Tardíos. Boletín del Instituto Francés de Estudios Andinos 33 (3): 403-423.

Eeckhout, P. 2004b. Relatos Míticos y Practicas Rituales en Pachacamac. Boletín del Instituto Francés de Estudios Andinos 33 (1): 1-54.

Eeckhout, P. 2008. Informe de las excavaciones. Proyecto
Ichma. Investigaciones Arqueológicas en el sitio de Pachacamac. Temporada 2008 - Informe Final, D, 24115. Universidad Libre de Bruselas - Fondo Nacional Belga de la Investigación Científica. Lima y Bruselas. Ms.

Engel, F. 1987. Menestras, cerámica y maíz. En De las begonias al maíz, vida y producción en el Perú antiguo, Capítulo III, pp. 89-146. Universidad Nacional Agraria La Molina. Lima.

Hocquenghem, A. 2005. Sacrificio y calendario ceremonial en las sociedades de los Andes Centrales. En Chamanismo y Sacrificio. Perspectivas arqueológicas y etnológicas en sociendades indígenas de America del Sur, editado por P. Chaumeil, R. Pineda y J. Bouchard., Tomo 179, pp. 75104. Serie de Trabajos del Instituto Francés de Estudios Andinos. Lima.

Paredes, P. y R. Franco. 1984. Descripción de los Hallazgos y Conclusiones acerca de las Excavaciones. Proyecto Pirámide con Rampa N³. Limpieza, Excavación y Consolidación de la Pirámide con Rampa No 3 -Informe de Campo, II y III, 4-13. Convenio COOPOP-INC. Lima. Ms.

Paredes, P. y R. Franco. 1989. Segunda Temporada de Trabajos-Primera Parte. Proyecto: Templo Viejo de Pachacamac. Segundo informe Parcial. 2 da Temporada de Excavaciones (Junio 1988-Abril 1989), 2, 44-54. INC - MSPACH. Fundación Augusto Wiesse. Lima. Ms.

Pozzi-Escot, D. y A. Chávez. 2009. Trabajo de Campo, Antecedentes, Excavación y Labores de Conservación. Informe Final de las labores de Conservación de Emergencia 2009, 13, 29-78. Instituto Nacional de Cultura - Museo de Sitio de Pachacamac. Lima. Ms.

Pozzi-Escot, D. y K. Bernuy. 2009. Resultados de los trabajos arqueológicos ejecutados en el Área de investigación. Proyecto de Investigación Arqueológica Calle Norte-Sur del Santuario de Pachacamac. Informe Final. Temporada I - Año 2009, D.1, 11-22. Instituto Nacional de Cultura. Lima. Ms.

Pozzi-Escot, D. y K. Bernuy. 2010a. Ubicación y descripción geográfica. Pachacamac: Calle Norte-Sur, Investigaciones Arqueológicas, 01, 7-12. Ministerio de Cultura. Lima. Ms.

Pozzi-Escot, D. y K. Bernuy. 2010b. Proyecto de Investigación Arqueológica Calle Norte-Sur y Segunda Muralla del Santuario de Pachacamac. Informe Final. Temporada II - Año 2010, 15-121. Ministerio de Cultura. Lima. Ms.

Rostworowski, M. 2009. Los atributos de Pachacamac y los animales relacionados a su culto. En Pachacamac. Obras Completas II, 2, pp. 42-46. Instituto de Estudios Peruanos. Lima, Perú.

Smith, H. y T. Jones. 1962. Raquitismo. Patología 
Veterinaria, 723-725. Traductor: Manuel Chavarría. Unión Tipográfica Editorial Hispano Americana. México.

Uhle, M. 2003. El cementerio de la Primera terraza sudoriental del Templo del Sol. En Pachacamac: Informe de la expedición Peruana Wiliam Pepper 1896, XX, pp. 327-339. Serie: Clásicos Sanmarquinos. Traductor: Manuel Beltroy. Fondo editorial UNMSM. Lima.

Weiss, P. 1976. El Perro Peruano sin pelo. Paleobiología, 1: 33-54. Museo Nacional de Antropología y Arqueología. Lima. 